\title{
Historical perspectives on global exports and research of African clawed frogs (Xenopus laevis)
}

\author{
Lance van Sittert ${ }^{1} \&$ G. John Measey ${ }^{2 *} \odot$ \\ ${ }^{1}$ Department of Historical Studies, University of Cape Town, Cape Town, South Africa; ${ }^{2}$ Centre for Invasion Biology, Department of Botany \& \\ Zoology, Stellenbosch University, Stellenbosch, South Africa \\ *Author for correspondence E-mail: john@measey.com
}

\begin{abstract}
Trade in live animals has been associated with populations of invasive species as well as the spread of disease. The African clawed frog, Xenopus laevis, was exported from its native region of southern Africa for use in pregnancy testing, and later for laboratory use as the model amphibian. We use historical export figures and publication records to detail the size and extent of the global trade. In addition, we explore the link between exports, scientific use, and invasive populations and chytrid outbreaks. Exports reached 400000 animals in the first 30 years from 1940, but only 86000 were sent outside Africa. Exports out of Africa peaked in the 1950s, while scientific publications using Xenopus laevis grew in the 1970s, coinciding with a rise in invasive populations and chytrid outbreaks. We show a lag between exports of Xenopus laevis and a rise in invasive populations of around 15 years. Our data demonstrate the global reach of the exports of Xenopus laevis from South Africa, and a later, much wider distribution via the scientific network which was supplied by secondary means outside of South Africa. We contend that our data demonstrate that by 1970, Xenopus laevis was the world's most widely distributed amphibian: institutions in $\mathbf{4 8}$ countries were supplied with live colonies on all continents except Antarctica. There is some evidence linking exports and scientific studies with invasive populations, but others appear to be linked to secondary distributors of this species.
\end{abstract}

Keywords: African clawed frog; Anura; historical biology; invasion biology; invasion debt; propagules; trade; Xenopus

\section{INTRODUCTION}

The global trade in wildlife is practically impossible to quantify, but is certainly worth billions of dollars (Karesh et al., 2005). The legal, international side of this trade shows trends that are ever increasing, and as they do so, the risks associated with wildlife trade become manifest. An increased threat of disease and the introduction of invasive species have been identified as resulting from wildlife imports into the USA (Smith et al., 2009). Disease can be transmitted to both humans (e.g. monkeypox), or to wildlife (e.g. paramyxovirus), with costs being associated with socioeconomics and healthcare on the one hand, and to threat of extinction on the other (Karesh et al., 2005). Invasive species are a global problem which impact severely on biodiversity, cost governments an estimated \$1.4 trillion annually (Ricciardi et al., 2011), and impact on the lives of individuals and communities the world over. Despite the very real problems associated with the global wildlife trade, there have been surprisingly few studies that have attempted to assess the historical trends for any taxa, no doubt due to the difficulties in piecing together data from disparate sources.

Biodiversity does not always respond to the immediacy of changes in the magnitude of disturbance (Essl et al., 2015a, b). Time lags between the cause and effect in ecosystems are very problematic with respect to policy decisions as they often fall outside of typical political cycles (Essl et al., 2015a). They also pose problems to researchers in the field as they rely on good historical evidence for events in previous generations that may have only recently had significance. However, when historical details are available, this can lead to meaningful policy changes which in turn can block invasion pathways (Wilson et al., 2009). The trade in live animals represents a significant invasion pathway, and is increasingly implicated for movement of disease, but few studies have attempted to reconstruct the historical basis for the trade and associated invasions.

Global trade in live amphibians has grown steadily over time (Herrel \& van der Meijden, 2014; Schlaepfer et al., 2005), and the result has been the widespread introduction of invasive populations as well as disease (Van Wilgen et al., 2008). One amphibian, the African clawed frog Xenopus laevis, became the centre of speculation (after Weldon et al., 2004) about the origin and spread of the chytrid fungus, Batrachochytrium dendrobatidis $(B d)$, widely thought to be associated with the catastrophic global decline of amphibians (Pounds et al., 2006; Stuart et al., 2004). Intensive research into $B d$ since its description in 1999 has shown that there are multiple strains of this pathogen, many of which appear to be endemic to areas outside of Africa (Rosenblum et al., 2013). For example, the fungus was present in North and South America (and Korea) more than 100 years ago (Fong et al., 2015; Rodriguez et al., 2014; Talley et al., 2015). This has led to two hypotheses, namely that catastrophic chytrid outbreaks have derived from indigenous strains, or that virulent strains have been 
transported along with the trade in amphibians (Rachowicz et al., 2005). It is therefore important to trace the introduction of novel, and possibly more virulent, strains into local systems via trade and/or invasive amphibian populations (Goka et al., 2009; Rosenblum et al., 2013). Invasive populations of African clawed frogs have now been recorded on four continents, and in some cases populations are thought to be beyond eradication (Measey et al., 2012). This frog has a special place in the history of 20th century science as it became one of four vertebrate species universally recognised as standard biological models representing all vertebrates (Travis, 2006). The history of the global trade in this species, therefore, has relevance both to invasion biology and the spread of disease.

The history of how African clawed frogs rose to prominence in academia has recently been compiled by Gurdon and Hopwood (2000). These frogs appeared on the international scene in the 1930s. During the 1940s, trade was mostly associated with the use of live animals for human pregnancy testing (Hogben, 1930; Shapiro \& Zwarenstein, 1946). These animals were sourced from private dealers in the South African Cape region (Cape Town and surrounds) until the late 1930s, when the trade was regulated and the Cape Provincial Administration (CPA) became the main suppliers (Hey 1949). The pregnancy test was in use until an immunological assay was developed in the 1960s. Xenopus laevis became the amphibian of choice for embryologists as a result of year round availability of embryos, and the establishment of normal tables (Nieuwkoop \& Faber, 1956). Due to the hardy nature of laboratory colonies of X. laevis (see Measey et al., 2012), other scientists were attracted from fields which included biochemistry, cellular studies and genetics. The number of scientific fields that use $X$. laevis continues to grow, and with them laboratory colonies. Despite assertions that $X$. laevis is the world's most widely distributed species (e.g. Measey et al., 2012), the global distribution remains undocumented.

Weldon et al. (2007) attempted to quantify the trade in $X$. laevis, but their quantification of the export trade prior to 1998 was derived from the published annual reports of the Cape Provincial Administration Department of Nature Conservation whose Jonkershoek and Pirie fish hatcheries were the official suppliers of Xenopus laevis to both national and international markets. This series is problematic for several reasons. Firstly, data on X. laevis sales were not published for 11 of the 34 years (1941-1974) in which the CPA traded in $X$. laevis. Secondly, the published data indicated exports in only 11 out of 23 years, and destination is recorded by continent only. Weldon et al. (2007) thus only provided a total sales figure of $340000 \mathrm{X}$. laevis for two thirds of the period in which the CPA participated in the trade. As they were unable to detail exports over the period 1941-1997 they failed to demonstrate their central contention of global pathogen dissemination pathway via trade in $X$. laevis.

We accessed the unpublished archives of the Jonkershoek fish hatchery housed in the Cape Town Records Centre (TBK) of the National Archives and Records Services (NARS) which provide a much more complete and higher resolution reconstruction of the CPA trade in X. laevis. The archive contains data on every individual sale made by the hatchery for 28 of 34 years (the orders for 1956 and 1970-1974 could not be traced, although the latter are thought to have been retained at Jonkershoek), including the number and sex of frogs and the name and street address of the purchaser. This allowed Jonkershoek's annual $X$. laevis sales to be quantified by sex and destination and the latter to be plotted at global, continental and national scales.

The source of animals for invasive populations, and thus putatively introducing chytrid fungus into the environment, is not well understood, but is thought to originate from pregnancy clinics, scientific laboratories and the pet trade (Kraus, 2008; Measey et al., 2012). In this study, we attempt to reconstruct a complete trade record of exports of $X$. laevis from South Africa, and trace this through the first 50 years of its use and establishment in science as the global model amphibian. To approximate the existence of colonies of X. laevis in scientific laboratories throughout the world, we used publications in the scientific literature which featured 'Xenopus laevis' in their title as a proxy. In addition, we show the relative timing of the establishment of known invasive populations and chytrid fungal infections, and discuss how the trade in animals from South Africa or laboratory colonies may have impacted this.

\section{MATERIALS AND METHODS}

The Jonkershoek $X$. laevis sales archive is housed in the Cape Town Record Centre (TBK) in the PAF (C-SJ Group) Cape Provincial Administration: Department of Nature Conservation: Jonkershoek Fisheries (1912-1970). The archive comprises 11 box files (B1, B13-22 and B84) containing 28 individual order files and related correspondence in roughly chronological order including a single file (B84) of orders filled by the Pirie hatchery, King Williams Town, in the summer rainfall region in the period 1949-1957 (see Appendix 1). The files were deposited in 1976 in accordance with the requirement of the then Archives Act (No. 6 of 1962). The archives have been housed in the TBK since receipt and have not been weeded. They can be searched on the National Automated Archival Information Retrieval System (NAAIRS) accessible at http:// www.national.archives.gov.za/. They were located on the NAAIRS by performing keyword searches of all NARS repositories (RSA) with the terms 'frog(s)', 'X. laevis' and 'padda(s)' (the Afrikaans word for frog/s). The files were called up at the main Cape Town Archives Repository in Roeland Street, Cape Town, read in series sequence, and the individual order data captured on a spreadsheet using the fields; invoice no., receipt no., SA, export, year, month, day, purchaser, address, city, female $\mathrm{Xl}$ no., male $\mathrm{Xl}$ no., total $\mathrm{Xl}$ no., cost per frog (cents), cost of shipment (cents), transport (cents), packing (cents), total cost of shipment (cents). The orders were sorted into chronological order, cleaned to remove any duplicates and analysed by year, quantity, sex and destination (Tables 1 \& 2 Supplementary Information). The X. laevis sales data contained in the published reports of the CPA, Department of Nature Conservation annual reports used by Weldon et al. (2007) were also extracted to check and to fill in gaps (1970-1974) in the archival series. The ancillary correspondence in the archival files and published annual reports was read for the qualitative information they contained about the trade.

A search in Web of Knowledge (WoK: Thomson Reuters, previously known as the Science Citation Index) was made for all publications with 'Xenopus laevis' in their title from 1930 to 1980. We recognise that this excludes many iterations that may have been relevant (e.g. X. laevis, African clawed frog, clawed frogs, platannas), but consider this a representative sample. We then recorded the town/city/state and country of the corresponding author and determined latitude and 
longitude for these from Google Maps (maps.google.com). Between 1930 and 1972, WoK did not record the address of the corresponding author in their database. For these first 655 publications we ascertained the address from journal websites and by sourcing the publication for 505 of them, the remainder could not be determined. While we acknowledge that the corresponding author of a paper with 'Xenopus laevis' in the title may not signify that a laboratory colony of $X$. laevis were present in that town, we suggest that this is likely in the majority of cases. In addition, we searched Google Scholar using the South African commercial suppliers listed in Nace et al. (1971) together with the term 'Xenopus', and listed the countries from the resulting publications.

The Global Mapping project Bd-Maps (http://www.Bd-maps. net/) database records all instances of the fungal pathogen Batrachochytrium dendrobatidis $(B d$ - the fungus that gives rise to chytridiomycosis), together with dates when specimens were collected, their latitude and longitude, and species in which $B d$ was diagnosed. We downloaded all data for wild caught individuals between 1930 (the earliest recorded specimen being 1933) and 1980. We then used the co-ordinates to plot the recorded instances of this disease around the globe. Lastly, we plotted the positions of invasive populations of X. laevis using Measey et al. (2012), Kraus (2008), Tinsley and McCoid (1996) and associated literature searches. We plotted populations as present within a decade if they are reported as established at any time within that decade, and continued to plot them until they were reported as absent.

\section{RESULTS AND DISCUSSION}

The archival reconstruction of Jonkershoek X. laevis sales significantly revises Weldon et al.'s (2007) estimates of the total number of animals sold from 340000 to over 400000 animals. It also yields a near complete list of all destinations to which $X$. laevis, collected from the winter rainfall population of the southwestern Cape, were exported by the CPA over the period 1941-1969 (excluding 1956). This provides baseline first confirmed arrival dates for $X$. laevis from the winter rainfall population in 97 destinations, many of which are novel in the literature (Table 1, supplemental data). Destinations supplied by the CPA occur in 32 countries in Asia, Australia, Africa, Europe and North America. An additional six countries were supplied by private suppliers (Table 3, supplemental data), expanding the continents supplied to include South America, and covering all continents except Antarctica. During the same period, we show that publications on $X$. laevis emerge from all six continents with 10 additional countries having publications with the species name in the

Table 1. Jonkershoek Xenopus laevis sales by destination and decade 1941-1969.

\begin{tabular}{lrrrr}
\hline Continent & $\begin{array}{c}\text { Number of } \\
\text { destinations }\end{array}$ & $\begin{array}{r}1940- \\
1949\end{array}$ & $\begin{array}{r}1950- \\
1959\end{array}$ & $\begin{array}{r}1960- \\
1969\end{array}$ \\
\hline Africa & 35 & 41833 & 118176 & 152163 \\
Asia & 6 & 450 & 1036 & 500 \\
Australasia & 8 & 1445 & 2325 & 344 \\
Europe & 39 & 6019 & 15263 & 16219 \\
North & 16 & 24273 & 14175 & 4368 \\
$\quad$ America & 104 & 74020 & 150975 & 173594 \\
Total & & & & \\
\hline
\end{tabular}

title. Thus by 1970, live colonies of the African clawed frog, Xenopus laevis, had been distributed to 48 countries on all continents except Antarctica, making it the world's most widely distributed species of amphibian. In comparison, the Cane Toad, Rhinella marina, was introduced to 28 countries in North and South America, Asia and Australia, while the North American Bullfrog, Lithobates catesbeiana, has been introduced to 36 countries in Asia, Europe, North and South America (Kraus, 2008). However, the comparison is not entirely equal as these latter records refer to introductions of alien populations, while those described for X. laevis refer to laboratory colonies.

To best illustrate the change in historical use over time, we have broken the period into 10-year time slices (Figure 1). Here we record results from our historical searches and discuss their consequences.

\section{0s}

Research on X. laevis was predominantly South African and Cape Town based, and covered a broad variety of topics including endocrinology, developmental biology, and reproduction. Other research was in London (L. Hogben, S.S. Alexander \& C.W. Bellerby), Edinburgh (F.A.E. Crew), Aberdeen (F.W. Landgrebe) and Baltimore (H. Jensen) and was associated with individual scientists who used this species in anatomical studies or the diagnosis of pregnancy (see Gurdon \& Hopwood, 2000). Prior to the commencement of trade from the CPA, animals were purchased from private dealers by both local and overseas users.

Although the distribution of the pathogen $B d$ is shown as being restricted to continental Africa, it should be remembered that other instances which predate this period are not shown (Fong et al. 2015; Huss et al. 2013; Talley et al. 2015).

\section{$1940 s$}

In response to the development of frog pregnancy testing in the 1930s, the CPA, concerned about the sustainability of private dealers' wild harvesting of $X$. laevis, sought to supplement this supply with frogs cultivated in its Jonkershoek hatchery. The hatchery, however, failed in its efforts to breed $X$. laevis and so from 1941 supplemented cultivation with wild caught $X$. laevis from private farm dams in the southwestern Cape (Hey, 1949). The hatchery relied on farmers to alert them to well-stocked dams and despatched catching teams within a $150 \mathrm{~km}$ radius of the hatchery during spring to trap in dams, paying farmers $1-3 \mathrm{~d}$ per frog (equivalent to USD 0.65 today). The wild caught $X$. laevis were held at Jonkershoek and distributed according to orders received by post. Frogs sold nationally were transported by rail in milk tins, and internationally by sea in custom-built metal cases each holding 100 frogs. The first air shipment of X. laevis was made in 1949, but this only became routine in the late 1960s and then only for ex-Africa sales.

During the 1940s, a total of 74020 African clawed frogs were shipped from CPA Jonkershoek, with $43.5 \%$ of these being shipped to destinations outside of Africa (Figure 1; Table 1, supplemental data). After African shipments (most of which were inside South Africa), North America took 32\% of animals, including two shipments to Ottawa, Canada, of a total of 1125 individuals and another consignment to Orlando, Florida, of 6650 X. laevis (see below).

The first report of an alien population of Xenopus laevis came from Ascension Island dating back to at least 1944 when a 


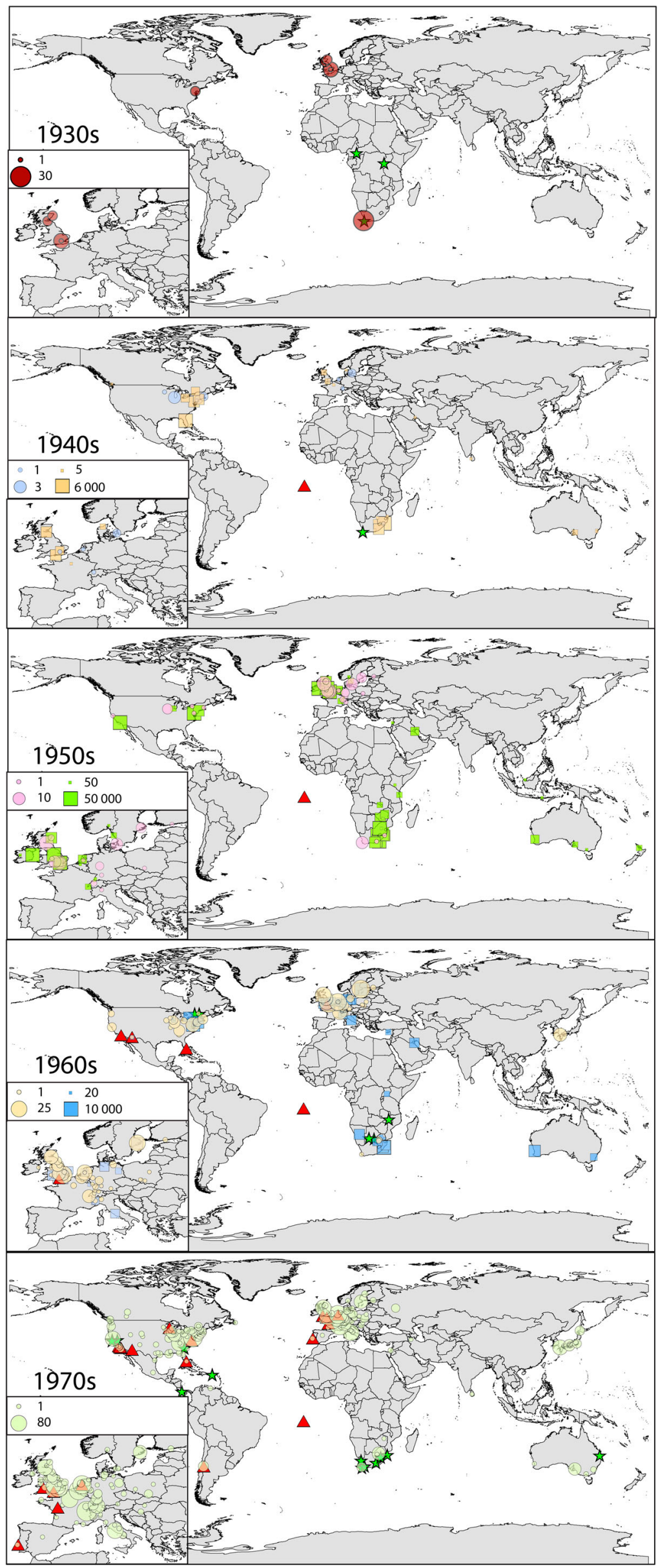

Figure 1. Decadal distribution of the African clawed frog (Xenopus laevis) through publications in journals (circles), shipments from the Cape Provincial Authority (squares) and invasive populations (triangles). Instances of chytrid outbreaks (from www.bdnet.org) are plotted as stars. The sizes of circles and squares are proportional to the number of publications and export of individuals, respectively (note the key in each panel indicates relative sizes). 
specimen was collected (Loveridge, 1959). Loveridge noted making a collection of animals near the summit of Green Mountain in the early 1950s. Tinsley and McCoid (1996) presumed these to have been released from exports during World War II, but we note that no exports were destined for Ascension Island, so we assume that these animals were intercepted (or escaped) from consignments destined for the USA when a boat docked there.

Interestingly, exports and research during the 1940s appear disassociated. Research was restricted to the USA, and a few locations in Europe, and notably absent in South Africa. This may be primarily due to the impact of World War II on research. Prominent work at this time included work on steroid hormones and information about breeding and care (F. Parker in Chicago, IL, USA and J.V. Thorborg in Copenhagen, Denmark). Meanwhile, exports were biased towards the USA, Canada, UK, Australia, Sri Lanka, Yemen, and some other European countries. Most exports made during this period appear to be linked to pregnancy testing.

\section{0s}

Jonkershoek abandoned efforts at cultivation after the war and all animals during the 1950s were from wild caught populations. The export demand levelled off due to the establishment of commercial breeding populations in the USA and the UK and the substitution of Xenopus laevis with local species for pregnancy testing (see Frazer \& Wohlzogen, 1950; Mainini, 1947; Mello, 1949; Robbins et al., 1947; Wiltberger \& Miller, 1948). Jonkershoek also prioritised supplying the national public health and research demand at cost before exporting. It is possible that these commercial breeding populations also engaged in exporting to third countries, for example Japan. The Director of Nature Conservation in the CPA, Douglas Hey, was also opposed to the commercialisation of the export trade on principle and prioritised supplying the national public health and research demand at cost before exporting any surplus stock. The bulk of its export trade was likewise directed into the public health and research network of the wider British Empire.

The vast majority of animals (78\%) exported from Jonkershoek were supplied for dissection to tertiary education institutions in southern and eastern Africa. It is notable that most of these were inside the known distribution of X. laevis (see Furman et al., 2015), and those that were not have local species that could have been adequate. Exports expanded to an increasing number of global destinations, and peaked in terms of numbers exported out of Africa. California (Los Angeles) received its first shipment of approximately 10000 African clawed frogs during the 1950s (see below).

Many areas producing research were supplied by Jonkershoek, although outside of the main areas of research (South Africa, Europe and USA) many exports occurred to areas without any publications in the 1950s (e.g. Australia, New Zealand, Indonesia, Yemen), suggesting that the main demand was for pregnancy testing in state public health systems. In Europe, a sizeable area in the East received no animals from Jonkershoek, although it produced many publications, suggesting the continued presence of private dealers in the market (both in South Africa and elsewhere) despite, or perhaps because of, Jonkershoek flooding it with cost price animals. Alternatively, these laboratories may have been seeded with stocks from collaborating scientists (see below).
The only known invasive population during the 1950s was still on Ascension Island.

\section{0s}

The steady, rising demand for female X. laevis for pregnancy testing from both state and private pathology laboratories in Britain and its empire, including South Africa, comprised $31.5 \%$ of sales. This demand disappeared by the mid-1960s when the frog test was replaced by chemical pregnancy tests. The slack was taken up by surges in demand from the tertiary education sector in South Africa and developmental biologists abroad, who had adopted $X$. laevis as a model amphibian for developmental work (see Gurdon \& Hopwood, 2000). This was reflected in an increase in the volume of CPA sales to private dealers (11.1\% of all sales).

Significant scientific advances were being made using $X$. laevis as a model organism. In 1962, J. Gurdon discovered the reversibility of cell specialisation through replacement of DNA in Xenopus eggs (Gurdon, 1962). This work eventually led to his receiving a joint Nobel Prize in Physiology in 2012. The total number of X. laevis-related publications rose to 352 (Figure 2).

Europe and USA were responsible for most published papers, but a number came out of Japan. There are no specific records of sales from Jonkershoek, pointing to the presence of private dealers, and/or the inter-institutional exchange of animals enabled by cheap and rapid air transport. It is notable that most publications do not match exports from Jonkershoek. There are occasional examples of publication lag, and indications that some laboratories may have taken animals left after pregnancy clinics ceased using frogs (e.g. Dublin, Ireland).

Chytrid infection outside the African continent was found from specimens of Rana clamitans from Saint-Pierre-de-Wakefield, Quebec in 1961 (Ouellet et al., 2005). This site is only $30 \mathrm{~km}$ from the city of Ottawa (see above and Table 1, supplemental data) where consignments were delivered in the 1940s, with aquatic corridors (Riviere Gatineau) and small lakes permeating the system.

This period coincided with the first invasive population established in Europe, on the Isle of Wight, by deliberate introduction around 1962, and associated with a pregnancy testing clinic (Tinsley \& McCoid, 1996). At the same time, multiple introductions were made in California, many of which are still present as invasive populations today (see Measey et al., 2012). Of note is the simultaneous shipment of animals, publication of papers, and the development of an invasive population in Tuscon, Arizona. This invasive population is believed to have resulted from a deliberate introduction (Tinsley \& McCoid, 1996). Another population in Florida coincided with large shipments made to Orlando in the 1940s. Many of these introductions in the 1960s have been recorded as deliberate (Kraus, 2008; Measey et al., 2012; Tinsley \& McCoid, 1996).

\section{0s}

Exports declined from more than $40 \%$ of sales in the mid1940 s to less than $10 \%$ by the mid-1970s. This reflected the CPA policy of giving precedence to the national market and refusing to supply foreign wholesale dealers, not a decline in international demand which was increasingly supplied by private dealers in South Africa and abroad (see Nace et al., 1971). Nace et al. (1971) listed seven ex-South African 
commercial suppliers; three in the USA (one in Cockysville, MD and two in Oshkosh, WI), two in the UK (Littlehampton and Oxford) and one each in the Netherlands (Ermelo) and (then) Czechoslovakia (Svermova). Three were private companies, three researchers and one private individual. More than half $(55.6 \%)$ of Jonkershoek X. laevis were sold to the tertiary education sector for teaching and research almost entirely in South Africa (93.8\% of tertiary education sales) (see Figure 2).

Research output had quadrupled, with the USA and most countries in Europe having produced many papers. Research was spreading east into Russia, and Japan rose to prominence. Australia was also starting to produce research on $X$. laevis, including many of the cities that had received exports from Jonkershoek in previous decades.

Infections of $B d$ were found on the East and West coasts of North America including Quebec, Canada (Ouellet et al. 2005). Australia also recorded the first presence of $B d$, which also appeared in the Caribbean and Central America, areas that have no known historic connection with $X$. laevis. During the 1970s invasive colonies of this species were widespread in the USA, Europe and Japan (although Japan's invasive population was not recorded until the 1990s; Measey et al., 2012). Additional invasive populations appeared in Santiago (Chile) and Lisbon (Portugal) within the same decade that the first publications appeared in those countries. The Lisbon invasion is thought to be directly related to escape from a research facility (see below), and while the origin of the Chilean invasion is unknown, it seems likely that it too originates from research.

\section{0s onwards}

In the penultimate decade of the 20th century South African exports of Xenopus laevis were constrained by anti-apartheid sanctions abroad. The passing of the Comprehensive AntiApartheid Act in the United States in 1986 closed the lucrative American market for five years and importers everywhere were encouraged to source $X$. laevis from suppliers other than those in South Africa. The export trade rebounded strongly after the abolition of apartheid in 1994 despite new conservation controls on the wild harvesting of X. laevis in the Western Cape. More than 71500 X. laevis were exported from the province under the new permit system in six years (1998-2004) alone (Weldon et al., 2007), roughly three quarters of the total exported by Jonkershoek over 35 years (1941-1974).

\section{Relationships between exports, publications, introduced populations and disease}

Our data show a surprisingly poor link between exports of $X$. laevis from the CPA and the far greater numbers of institutions where research was being undertaken on $X$. laevis. Although large numbers of animals were shipped from Jonkershoek to many major research areas, especially in the UK and the USA, publications arose from areas which had apparently received no animals from the CPA. We attribute this discrepancy both to the (unrecorded) trade by private dealers in South Africa since 1970, but also to secondary trade from laboratories undertaking research and passing on viable colonies for use. We acknowledge that our use of 'Xenopus laevis' in the title of a research publication does not guarantee the presence of a laboratory colony at the corresponding author's address. Especially as some of the publications would not have relied on live animals, and others may have resulted from the work being carried out at other institutions. In addition, we did not include many other publications on this species that, for example, did not have the full Latin name in the title. However, we feel that this does give a conservative estimate of the geographic areas in which researchers kept colonies of African clawed frogs. In addition, our search accurately located laboratories which kept live animals when these were not reflected in exports from the South African CPA, for example in Lisbon, Portugal.

Examples of secondary movement of laboratory stocks can be seen in our literature records. In 1968, a consignment of $200 \mathrm{X}$. laevis (120 females and 80 males) were sent to Dr M. Balls at the University of East Anglia in Norwich, who had been publishing work on the African clawed frog since the early 1960s (Balls, 1962). The same department has hosted researchers working with $X$. laevis and this has continued to the present day. The physiologist, Dr G. Shelton, also worked on $X$. laevis and trained various students including Dr M. Emilio (e.g. Emilio \& Shelton, 1974). Emilio continued working on African clawed frogs when she returned to Lisbon, Portugal (e.g. Costa et al., 1989). The invasive population of X. laevis in Lisbon is believed to have been established in the late 1970s when the basement animal facility, which housed Dr Emilio's frogs, flooded (see Measey et al., 2012). Whether or not this sequence resulted in an invasive population descended from the same animals (or even including the same animals given their longevity, see Measey, 2001) that were shipped in 1968 is unknown, but this example does serve to show the potential for connectivity between shipments from the CPA, researchers and the secondary movement of colonies of $X$. laevis.

In addition to the disjunction between CPA supplies and research, there appears to be no direct link between CPA supplies or research and invasive populations. While some invasive populations did have clear links with research (e.g. France, Portugal, see Measey et al., 2012), others result from these animals being kept inside the workplaces or homes of people who were curious or had a misplaced sense of ethics. The secondary trade in $X$. laevis as pets appears to be responsible for several invasive populations (e.g. Humberside, UK and Florida, USA, see Measey et al. 2012), as well as an unknown number of individuals released into the environment. Our findings illustrate that $X$. laevis were not shipped from South Africa for the pet trade. Clearly, animals originally intended for pregnancy clinics or scientific laboratories have moved into the pet trade, probably through secondary distributors, and from there into the environment. This secondary spread, from areas supplied by South Africa to other laboratories has not been investigated, yet the historical scale of these secondary movements is likely to be of relevance.

We did find some support for the suggestion that CPA exports were chronologically concordant with certain chytrid outbreaks. An early chytrid outbreak in North America occurred north of Ottawa, Canada in 1961, 10-14 years after 1125 individuals were sent there. Extensive studies of chytrid in this region suggest that in subsequent years, the fungus spread to several other species throughout the St Lawrence River Valley of Québec including the American bullfrog, Lithobates catesbeiana (Ouellet et al., 2005). Although chytrid is known to have been present in North America prior to this record (Huss et al., 2013; Talley et al., 2015), it is thought that novel strains of the pathogen from other areas may have higher impacts on native species, and that these are facilitated 
(a)

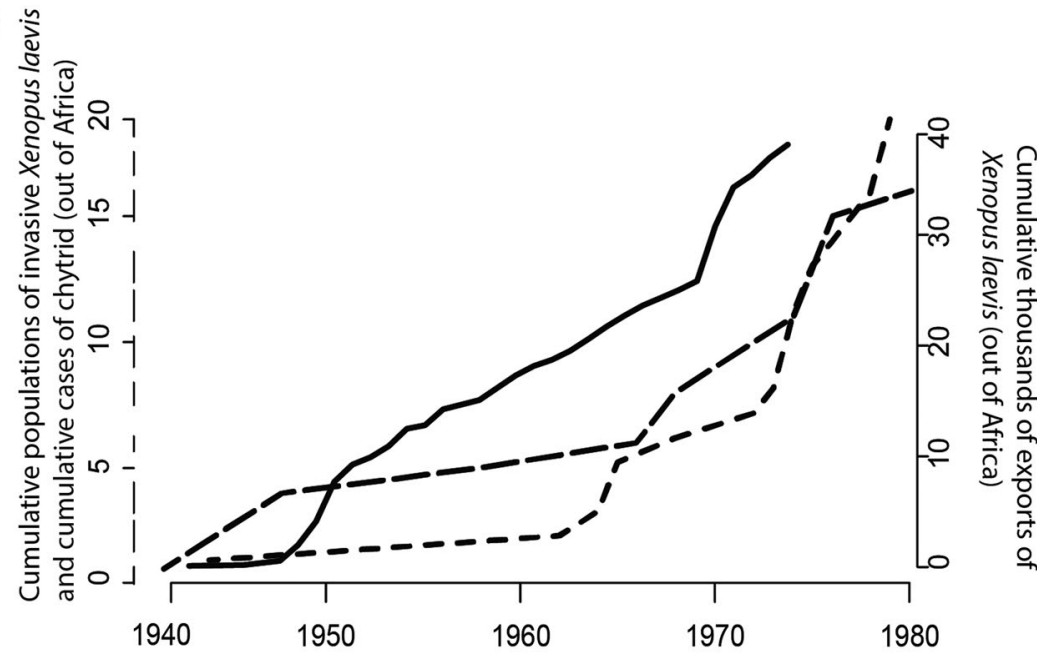

(b) $\because$

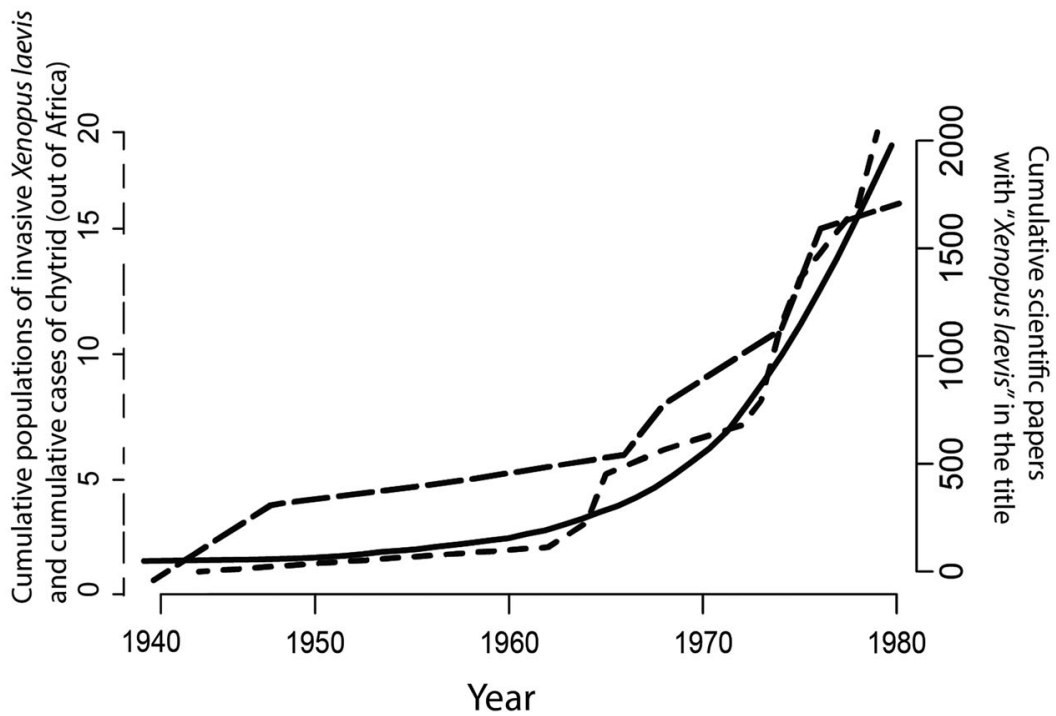

Figure 2. Cumulative numbers of invasive populations of African clawed frogs (Xenopus laevis) and outbreaks of chytrid fungus are shown on the left abscissa. (a) shows the cumulative exports of $X$. laevis from the Cape Provincial Authority while (b) shows the cumulative number of scientific papers with 'Xenopus laevis' in the title.

by invasive anurans including L. catesbeiana (see Goka et al., 2009; Rosenblum et al., 2013). This is notable as trade in this species is also thought to be responsible for disseminating chytrid globally (e.g. Goka et al., 2009; Schloegel et al., 2009).

\section{Invasion debt}

Despite more than 200000 individual X. laevis being shipped from South Africa in the 1940s and 1950s (Table 1), it was not until 15 years after global dissemination of this species in the 1960s and 1970s that invasive populations started to grow. In many cases, it appears that this lag is owing to a move from the use of the species for pregnancy testing, to laboratory animals, and then into the pet-trade (Measey et al., 2012). Figure 2 shows the numbers of invasions to have undergone a sharp increase in the 1960s. Invasions are ongoing, with more being uncovered in the 21st century (Measey et al., 2012; Peralta-García et al., 2014). In addition, the cryptic nature of this principally aquatic species may make detection difficult and it is possible that more invasive populations exist, but are yet to be discovered.
The lag between the export of African clawed frogs by the CPA and a rise in invasive populations of around 15 years (Figure 2a) could represent original animals shipped, or 3 to 7 generations depending on the location (see Measey, 2001). We show that the rise in invasive populations occurs simultaneously with a rise in chytrid outbreak, although we do not suggest causation. The late 1960s and 1970s show an exponential increase in the use of $X$. laevis in laboratories worldwide, and this coincides with increases in both invasive populations and chytrid outbreaks (Figure $2 b$ ).

\section{Genetic implications of trade}

Around $60 \%$ of African clawed frogs were sold to buyers in 30 locations within the range of Xenopus laevis and other Xenopus species in Africa (see Figure 1). It seems possible that some of these animals may have made their way out of laboratories and into their local environment. Jonkershoek falls into a clade of $X$. laevis which is known to occur in the southwestern Cape: 'Cape clade'. Although the full extent of this clade is not well understood, it occurs from around Vredendal in the north, to Knysna in the east (Furman et al., 
2015; Measey \& Channing, 2003). The Cape Fold mountains appear to harbour at least three other clades that extend north and east, and while these are not thought to represent separate species, their genetic divisions are thought to amount to 4-5 My of evolution (Furman et al., 2015). Should exports from Jonkershoek be released at their destinations, they would be in the presence of a different genetic clade. This would make such releases genetically identifiable, and potentially cause changes in the genetic make-up of $X$. laevis in some of its native range.

Within Africa, but outside of the range of $X$. laevis, there are no introductions known, although it is not possible to say that none have occurred. As X. laevis is able to hybridise with many of its congeners (Graf \& Kobel, 1991), any such populations may pose a threat to local species, although no threatened Xenopus species are known from the areas to where $X$. laevis were shipped. Outside of Africa, we would expect that populations of invasive $X$. laevis would belong to the 'Cape clade', as has already been found in Italy, Chile and Portugal (De Busschere et al., 2016; Lillo et al., 2013; Lobos et al., 2014), however the French invasion appears to have a far more complex history with clades from throughout the native range being represented (De Busschere et al., 2016). By the time the CPA withdrew from the market the export demand for $X$. laevis was for developmental biology research (Gurdon \& Hopwood, 2000). In the early 1970s, Nace et al. (1971) compiled a comprehensive list of 11 global suppliers of $X$. laevis; 5 in South Africa (including Jonkershoek), 3 in the USA, 2 in the UK and 1 in the Netherlands. One each of the American (J. Cook: Cockeysville, MD), British (Gerrard and Haig: Littlehampton) and South African (D. Muller: Johannesburg) private dealers sourced their X. laevis from Jonkershoek. Two of the other three South African private X. laevis dealers were located in Cape Town (D. Wood: Snake Farm, Fish Hoek) and Stellenbosch (P. van den Elzen) all in the winter rainfall region, and 'Cape clade'. All supplied only wild caught X. laevis, from within the 'Cape clade' (van Elzen and Jonkershoek, also dealing in X. gilli: Nace et al., 1971).

However, we are also aware that there is the possibility that exports came from elsewhere in South Africa, within the regions of genetic clades other than the 'Cape clade'. The last South African supplier mentioned by Nace et al. (1971) was from Port Elizabeth (D.M. Pinker: Walmer) in the summer rainfall region. A private shipment of $10000 \mathrm{X}$. laevis was reported from Port Elizabeth to an unknown foreign destination (South African Shipping News and Fishing Industry Review). Currently, there have been no studies that would suggest which clade would be found in the area, and this adds to a growing need to define the endemic intraspecific biodiversity of this species. In addition, the CPA was known to fill orders with animals from the Pirie hatchery near King Williams Town, Eastern Cape. However, close inspection of these records show that they were all sent to South African institutions on the east coast (e.g. Durban, East London). It is not yet known whether the native genetic lineages in these areas are the same as those from the Pirie source.

\section{Private dealers}

While it may be true that there are no quantitative data on the private frog trade for the period 1974-1997 (Weldon et al., 2007), its scope can be delineated through the use of a bibliographic proxy. The only private South African dealer to register on the Google Scholar keyword search was the Snake Farm in
Fish Hoek which yielded 215 discrete institutional reports in scientific journals from 14 different countries over a period of 37 years 1968-2005. The most striking contrast with CPA sales was the complete absence of South African, African or Australasian institutions. While some of the pathology laboratories in these regions likely stopped buying $X$. laevis after decolonisation and/or the discontinuation of frog pregnancy tests in the 1960s, the continued demand of the tertiary education sector was primarily for male $X$. laevis for teaching and thus invisible to this source.

Four countries $(28.6 \%$ ) accounted for $79.1 \%$ of all published papers utilising Snake Farm supplied X. laevis; the USA (86 papers), Germany (34 papers), Switzerland (26 papers) and the UK (24 papers). Three other countries, Israel (15 papers), Belgium (11 papers) and France (8 papers), accounted for a further $15.8 \%$ with the remainder made up by Chile (3 papers), Canada ( 2 papers), Italy ( 2 papers), China (1 paper), Greece (1 paper), Japan (1 paper) and Spain (1 paper) (see Figure 1).

Temporally, the proxy Snake Farm sales data clearly reflect the withdrawal of the CPA from the market in 1974, the combined deleterious effects of anti-apartheid sanctions abroad, and the increasing restriction of wild capture on the Snake Farm's market after the mid-1980s. Spatially, the proxy Snake Farm sales data yield 63 locations outside Africa, 52 of which were not supplied by the CPA, together with approximate dates of first arrival. These locations are both in the CPA's traditional European and North American export markets and in nascent markets in South America (Chile), Israel and East Asia (China and Japan).

\section{CONCLUSION}

More than 2100 orders comprising in excess of 400000 $X$. laevis were filled by the CPA Jonkershoek in 28 years (1941-1969) to 104 specified global destinations. Pirie's output was small, intermittent and only supplied the Eastern Cape and Kwa-Zulu Natal demand. A surprisingly high number of frogs were supplied for dissection within southern Africa, where dissection was already well established in tertiary education institutions (and this practice continues today). We provide details of 69 destinations and 86000 animals that were sent outside Africa. We demonstrate that during this period, the number of colonies in laboratories around the world was much higher, with 254 locations producing publications with 'Xenopus laevis' in the title. The secondary trade that supplied these laboratories may be implicated in establishing invasive populations. We demonstrate an invasion lag for African clawed frogs between the movement of animals from Jonkershoek, and a rise in invasive populations which occurred some 15 years later. We contend that our data demonstrate the African clawed frog as the world's most widely distributed amphibian, reaching all continents (except Antarctica) by the mid-1970s. Lastly, we provide new evidence on shipments of $X$. laevis which may be of interest to those studying the spread of novel strains of the chytrid fungus pathogen.

While this study represents a significant advance on previous attempts to reconstruct the CPA trade from its published reports alone, it is important to recognise that the CPA was not the only dealer in the national market and that private dealers effectively remain 'ghosts' glimpsed before 1997 only through proxies such as the scholarly output of their clients. African and ex-African private dealer sales records which are 
comparable in quality and span to those of the CPA are urgently required. Only then will it be possible to map the full extent of the scale and scope of $X$. laevis trade over the second half of the 20th century. This will enable us to adequately address the many and far-reaching legacies and consequences which exist today.

\section{ACKNOWLEDGEMENTS}

We would like to thank Philip Purnell (Thomson Reuters) for facilitating access to early WoK searches. Hendré van Rensburg (NRF student assistantship) and Marié Theron for their help with address searches from early published literature. John Wilson, Rui Rebelo, Thalassa Matthews and two anonymous reviewers gave helpful comments on an earlier version of this manuscript. JM would like to thank the DST-NRF Centre of Excellence for Invasion Biology for making this study possible.

\section{FUNDING}

This research was funded by the National Research Foundation of South Africa (NRF grant no. 87759 to GJM) and NRF incentive funding to GJM.

\section{SUPPLEMENTAL DATA}

Supplemental data for this article can be accessed here.

\section{ORCID}

\section{G. John Measey (D) http://orcid.org/0000-0001-9939-7615}

\section{References}

BALLS, M. 1962. Methylcholanthrene-induced lymphosarcomas in Xenopus laevis. Nature 196: 1327-1328.

Costa, P.F., Emilio, M.G., Fernandes, P.L., Ferreira, H.G. \& Ferreira, K.G. 1989. Determination of ionic permeability coefficients of the plasmamembrane of Xenopus laevis oocytes under voltage clamp. Journal of Physiology-London 413: 199-211.

De Busschere, C., Courant, J., Herrel, A., Rebelo, R., Rödder, D., Measey, G.J. \& BACKELJAU, T. 2016. Unequal contribution of native South African phylogeographic lineages to the invasion of the African clawed frog, Xenopus laevis, in Europe. PeerJ 4: e1659.

EMILIO, M.G. \& Shelton, G. 1974. Gas-exchange and its effect on bloodgas concentrations in amphibian, Xenopus laevis. Journal of Experimental Biology 60: 567-579.

Essl, F., Dullinger, S., Rabitsch, W., Hulme, P.E., PYšEK, P., Wilson, J.R. \& RichARDSON, D.M. 2015a. Delayed biodiversity change: no time to waste. Trends in Ecology \& Evolution 30: 375-378.

Essl, F., Dullinger, S., Rabitsch, W., Hulme, P.E., PYšek, P., Wilson, J.R. \& RICHARDSON, D.M. 2015b. Historical legacies accumulate to shape future biodiversity in an era of rapid global change. Diversity and Distributions 21: 534-547.

Fong, J.J., Cheng, T.L., Batallle, A., Pessier, A.P., Waldman, B. \& VREDENBURG, V.T. 2015. Early 1900s detection of Batrachochytrium dendrobatidis in Korean amphibians. PloS one 10: e0115656.

Frazer, J. \& Wohlzogen, F. 1950. Male British toad as a pregnancy test animal. British Medical Journal 2: 330.

Furman, B.L.S., Bewick, A.J., Harrison, T.L., Greenbaum, E., Gvoždík, V., Kusamba, C. \& Evans, B.J. 2015. Pan-African phylogeography of a model organism, the African clawed frog 'Xenopus laevis'. Molecular Ecology 24: 909-925.

Goka, K., Yokoyama, J., Une, Y., Kuroki, T., Suzuki, K., NaKahara, M., Kobayashi, A., Inaba, S., Mizutani, T. \& HYatT, A.D. 2009. Amphibian chytridiomycosis in Japan: distribution, haplotypes and possible route of entry into Japan. Molecular Ecology 18: 4757-4774.

Graf, J.-D. \& Kobel, H.R. 1991. Genetics of Xenopus laevis. In B.K. Kay and H.B. Peng (Eds), Xenopus laevis: Practical uses in cell and molecular biology. San Diego, CA, Academic Press. pp. 19-34.
GuRDON, J.B. 1962. Adult frogs derived from the nuclei of single somatic cells. Developmental Biology 4: 256-273.

Gurdon, J.B. \& Hopwood, N. 2000. The introduction of Xenopus laevis into developmental biology: of empire, pregnancy testing and ribosomal genes. International Journal of Developmental Biology 44: 43-50.

Herrel, A. \& VAn der MeidDen, A. 2014. An analysis of the live reptile and amphibian trade in the USA compared to the global trade in endangered species. Herpetological Journal 24: 103-110.

HeY, D. 1949. A report on the culture of the South African clawed frog Xenopus laevis (Daudin) at the Jonkershoek inland fish hatchery. Transactions of the Royal Society of South Africa 32: 45-54.

HogBen, L. 1930. Some remarks on the relation of the pituitary gland to ovulation and skin secretion in Xenopus laevis. Proceedings of the Royal Society of South Africa 22: 17-18.

Huss, M., Huntley, L., Vredenburg, V., Johns, J. \& Green, S. 2013. Prevalence of Batrachochytrium dendrobatidis in 120 Archived Specimens of Lithobates catesbeianus (American Bullfrog) Collected in California, 1924-2007. EcoHealth 10: 339-343.

Karesh, W.B., СooK, R.A., Bennett, E.L. \& Newcomb, J. 2005. Wildlife trade and global disease emergence. Emerging Infectious Diseases 11: 1000-1002.

Kraus, F. 2008. Alien Reptiles and Amphibians: A scientific compendium and analysis. Amsterdam, Springer Science \& Business Media.

Lillo, F., Dufresnes, C., Faraone, F.P., Lo Valvo, M. \& Stöck, M. 2013. Identification and potential origin of invasive clawed frogs Xenopus (Anura: Pipidae) in Sicily based on mitochondrial and nuclear DNA. Italian Journal of Zoology 80: 566-573.

Lobos, G., Mendez, M.A., CatTan, P. \& JaKsic, F. 2014. Low genetic diversity of the successful invasive African clawed frog Xenopus laevis (Pipidae) in Chile. Studies on Neotropical Fauna and Environment 49: 50-60.

LOVERIDGE, A. 1959. Notes on the present herpetofauna of Ascension Island. Copeia 1959: 69-70.

MaININI, C.G. 1947. Pregnancy test using the male toad. The Journal of Clinical Endocrinology \& Metabolism 7: 653-658.

Measey, G.J. 2001. Growth and ageing of feral Xenopus laevis (Daudin) in South Wales, UK. Journal of Zoology 254: 547-555.

Measey, G.J. \& Channing, A. 2003. Phylogeography of the genus Xenopus in southern Africa. Amphibia-Reptilia 24: 321-330.

Measey, G.J., Rödder, D., Green, S.L., Kobayashi, R., Lillo, F., Lobos, G., Rebelo, R. \& Thirion, J.-M. 2012. Ongoing invasions of the African clawed frog, Xenopus laevis: a global review. Biological Invasions 14: 2255-2270.

MeLLo, M.I. 1949. Care and maintenance of toads and frogs in captivity, for the performance of Galli Mainini's pregnancy test. The Journal of Clinical Endocrinology \& Metabolism 9: 1372-1378.

NACE, G.W., WAage, J.K. \& Richards, C.M. 1971. Sources of amphibians for research. BioScience 21: 768-773.

NieuwKoOp, P.D. \& FABER, J. 1956. Normal table of Xenopus laevis (Daudin). Amsterdam, North Holland Publishing Company.

Ouellet, M., Mikaelian, I., Pauli, B.D., Rodrigue, J. \& Green, G.M. 2005. Historical evidence of widespread chytrid infection in North American amphibian populations. Conservation Biology 19: 1431-1440.

Peralta-García, A., Valdez-Villavicencio, J.H. \& Galina-Tessaro, P. 2014. African clawed frog (Xenopus laevis) in Baja California: a confirmed population and possible ongoing invasion in Mexican watersheds. The Southwestern Naturalist 59: 431-434.

Pounds, J.A., Bustamante, M.R., Coloma, L.A., Consuegra, J.A., Fogden, M.P., Foster, P.N., La Marca, E., Masters, K.L., Merino-Viteri, A. \& PusChendORF, R. 2006. Widespread amphibian extinctions from epidemic disease driven by global warming. Nature 439: 161-167.

Rachowicz, L.J., Hero, J.-M., Alford, R.A., Taylor, J.W., Morgan, J.A., VredenburG, V.T., Collins, J.P. \& BrigGs, C.J. 2005. The novel and endemic pathogen hypotheses: competing explanations for the origin of emerging infectious diseases of wildlife. Conservation Biology 19: 1441-1448. 
Ricciardi, A., Palmer, M.E. \& Yan, N.D. 2011. Should biological invasions be managed as natural disasters? BioScience 61: 312-317.

RoBbins, S.L., PARKER JR, F. \& FrAnco, P.D. 1947. The reaction of the male South African clawed frog (Xenopus laevis) to gonadotropins. Endocrinology 40: 227-229.

Rodriguez, D., Becker, C.G., Pupin, N., Haddad, C.F. \& Zamudio, K.R. 2014. Long-term endemism of two highly divergent lineages of the amphibian-killing fungus in the Atlantic Forest of Brazil. Molecular Ecology 23: 774-787.

Rosenblum, E.B., James, T.Y., Zamudio, K.R., Poorten, T.J., Ilut, D., Rodriguez, D., Eastman, J.M., Richards-Hrdlicka, K., Joneson, S. \& JENKINSON, T.S. 2013. Complex history of the amphibian-killing chytrid fungus revealed with genome resequencing data. Proceedings of the National Academy of Sciences 110: 9385-9390.

Schlaepfer, M.A., Hoover, C. \& DodD, C.K. 2005. Challenges in evaluating the impact of the trade in amphibians and reptiles on wild populations. BioScience 55: 256-264.

Schloegel, L.M., Picco, A.M., Kilpatrick, A.M., Davies, A.J., Hyatt, A.D. \& DASZAK, P. 2009. Magnitude of the US trade in amphibians and presence of Batrachochytrium dendrobatidis and ranavirus infection in imported North American bullfrogs (Rana catesbeiana). Biological Conservation 142: $1420-1426$

Shapiro, H. \& Zwarenstein, H. 1946. The Xenopus test for pregnancy. British Medical Journal 2: 752

Smith, K.F., Behrens, M., Schloegel, L.M., Marano, N., Burgiel, S. \& DASZAK, P. 2009. Reducing the risks of the wildlife trade. Science 324: 594 Stuart, S.N., Chanson, J.S., Cox, N.A., Young, B.E., Rodrigues, A.S., FisCHMAN, D.L. \& WALlER, R.W. 2004. Status and trends of amphibian declines and extinctions worldwide. Science 306: 1783-1786.

Talley, B.L., Muletz, C.R., Vredenburg, V.T., Fleischer, R.C. \& LiPs, K.R 2015. A century of Batrachochytrium dendrobatidis in Illinois amphibians (1888-1989). Biological Conservation 182: 254-261.

Tinsley, R.C. \& McCoID, M.J. 1996. Feral populations of Xenopus outside Africa. In R.C. Tinsley and H.R. Kobel (Eds), The Biology of Xenopus. Oxford, Oxford University Press. pp. 81-94.

TRAVIS, J. 2006. Is it what we know or who we know? Choice of organism and robustness of inference in ecology and evolutionary biology. American Naturalist 167: 303.

VAN WILGEN, N.J., RichardSON, D.M. \& BAARD, E.H.W. 2008. Alien reptiles and amphibians in South Africa: towards a pragmatic management strategy: science policy. South African Journal of Science 104: 13-20.

Weldon, C., DE Villiers, A.L. \& DU Preez, L.H. 2007. Quantification of the trade in Xenopus laevis from South Africa, with implications for biodiversity conservation. African Journal of Herpetology 56: 77-83.

Weldon, C., Du Preez, L.H., Hyatt, A.D., Muller, R. \& Speare, R. 2004. Origin of the amphibian chytrid fungus. Emerging Infectious Diseases 10: 2100.

Wilson, J.R., Dormontt, E.E., Prentis, P.J., Lowe, A.J. \& Richardson, D.M 2009. Something in the way you move: dispersal pathways affect invasion success. Trends in Ecology \& Evolution 24: 136-144.

Wiltberger, P.B. \& Miller, D.F. 1948. The male frog, Rana pipiens, as a new test animal for early pregnancy. Science 107: 198.

\section{APPENDIX 1. HISTORICAL RECORDS OF XENOPUS LAEVIS EXPORTS}

\section{Cape Town Archives Repository (KAB)}

PAN30, A120/B/338, Supply of frogs from Jonkershoek trout hatchery. 1941-45.

PAS 3/192, P5, Inland fisheries. Culture of frogs. 1941-50.

\section{Cape Town Records Centre (TBK)}

PAF B1, C/A-Z (1), Jonkershoek fisheries. General. Includes applications for supply of fish and trout and frogs. 1944-45.
PAF B1, C/A-Z (2), Jonkershoek fisheries. General. Includes applications for supply of fish and trout and frogs. 1946.

PAF B1, C/A-Z (3), Jonkershoek fisheries. General. Includes applications for supply of fish and trout and frogs. 1947

PAF B1, C/A-Z (4), Jonkershoek fisheries. General. Includes applications for supply of fish and trout and frogs. 1966-69.

PAF B13, C/FO(1), Jonkershoek fisheries. Frog orders. Miscellaneous. 1942-43.

PAF B13, C/FO (2), Jonkershoek fisheries. Frog consignments. Miscellaneous. 1943.

PAF B13, C/FO (3), Jonkershoek fisheries. Frog consignments. Miscellaneous. 1943-65.

PAF B13, C/FO (4), Jonkershoek fisheries. Frog consignments. Miscellaneous. 1949.

PAF B14, C/FO (5), Jonkershoek fisheries. Frog consignments. Miscellaneous. 1951.

PAF B14, C/FO (6), Jonkershoek fisheries. Frog consignments. Miscellaneous. 1951-52.

PAF B14, C/FO (7), Jonkershoek fisheries. Frog consignments. Miscellaneous. 1952.

PAF B15, C/FO (8), Jonkershoek fisheries. Frog consignments. Miscellaneous. 1952-53.

PAF B15, C/FO (9), Jonkershoek fisheries. Frog consignments. Miscellaneous. 1953.

PAF B16, C/FO (10), Jonkershoek fisheries. Frog consignments. Miscellaneous. 1953-54.

PAF B16, C/FO (11), Jonkershoek fisheries. Frog consignments. Miscellaneous. 1954.

PAF B16, C/FO (12), Jonkershoek fisheries. Frog consignments. Miscellaneous. 1954-55.

PAF B17, C/FO (13), Jonkershoek fisheries. Frog orders. Miscellaneous. 1956-57.

PAF B18, C/FO (14), Jonkershoek fisheries. Frog orders. Miscellaneous. 1957.

PAF B18, C/FO (15), Jonkershoek fisheries. Frog orders. Miscellaneous. 1958.

PAF B19, C/FO (16), Jonkershoek fisheries. Classified frog orders. Miscellaneous. 1958-64.PAF B20, C/FO (17), Jonkershoek fisheries. Frog orders. Miscellaneous. 1959-60.

PAF B20, C/FO (18), Jonkershoek fisheries. Frog orders. Miscellaneous. 1959-64.

PAF B21, C/FO (19), Jonkershoek fisheries. Classified frog orders. Miscellaneous. 1959-69.

PAF B21, C/FO (20), Jonkershoek fisheries. Frog orders. Miscellaneous. 1961-62.

PAF B22, C/FO (21), Jonkershoek fisheries. Frog orders. Miscellaneous. 1963-64.

PAF B22, C/FO (22), Jonkershoek fisheries. Frog orders. Miscellaneous. 1966.

PAF B22, C/FO (23), Jonkershoek fisheries. Frog orders. Miscellaneous. 1967-68.

PAF B22, C/FO (24), Jonkershoek fisheries. Frog orders. Miscellaneous. 1969-70.

PAF B84, PH16B (1), Pirie trout hatchery. X. laevis orders. 1949-57.

PAF B131, PS8/3 (1), Jonkerhoek fisheries. Transportation of frogs. 1946-66.

\section{National Archives Repository, Pretoria (SAB)}

HEN 1370, 161/1/7, Horse and cattle breeding industry. Toads and frogs. 1945-60.

HLD 74, 78/33 (2), Public health. Snake bite serum and supply of Xenopus laevis toads. Also export of live frogs. 1963-65.

LDB 3354, R4302, Frogs. General correspondence. 1941-59. 